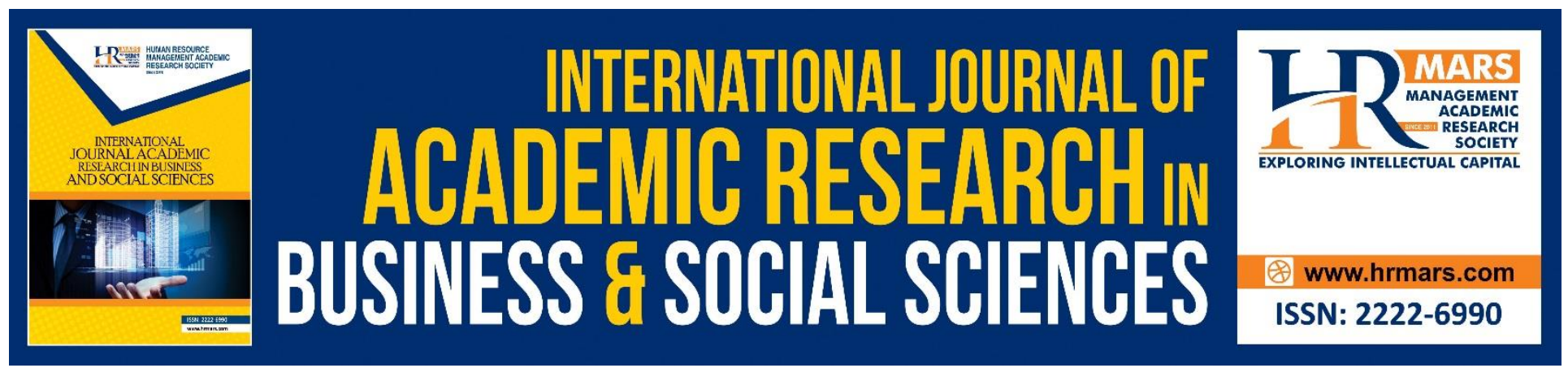

\title{
Protecting the Health of Children by Mandating Vaccination and Immunization: An Application of Usuli Principle of Istihsan
}

Nora Abdul Hak, Noraini Md Hashim, Roslina Che Soh@Yusoff

To Link this Article: http://dx.doi.org/10.6007/IJARBSS/v9-i5/5885

DOI: $10.6007 /$ IJARBSS/v9-i5/5885

Received: 15 March 2019, Revised: 12 April 2019, Accepted: 29 April 2019

Published Online: 30 May 2019

In-Text Citation: (Hak, Hashim, \& Soh@Yusoff, 2019)

To Cite this Article: Hak, N. A., Hashim, N. M., \& Soh@Yusoff, R. C. (2019). Protecting the Health of Children by Mandating Vaccination and Immunization: An Application of Usuli Principle of Istihsan. International Journal of Academic Research Business and Social Sciences, 9(5), 432-440.

Copyright: (C) 2019 The Author(s)

Published by Human Resource Management Academic Research Society (www.hrmars.com)

This article is published under the Creative Commons Attribution (CC BY 4.0) license. Anyone may reproduce, distribute, translate and create derivative works of this article (for both commercial and non-commercial purposes), subject to full attribution to the original publication and authors. The full terms of this license may be seen

at: http://creativecommons.org/licences/by/4.0/legalcode

Vol. 9, No. 5, 2019, Pg. 432 - 440

http://hrmars.com/index.php/pages/detail/IJARBSS

JOURNAL HOMEPAGE

Full Terms \& Conditions of access and use can be found at http://hrmars.com/index.php/pages/detail/publication-ethics 


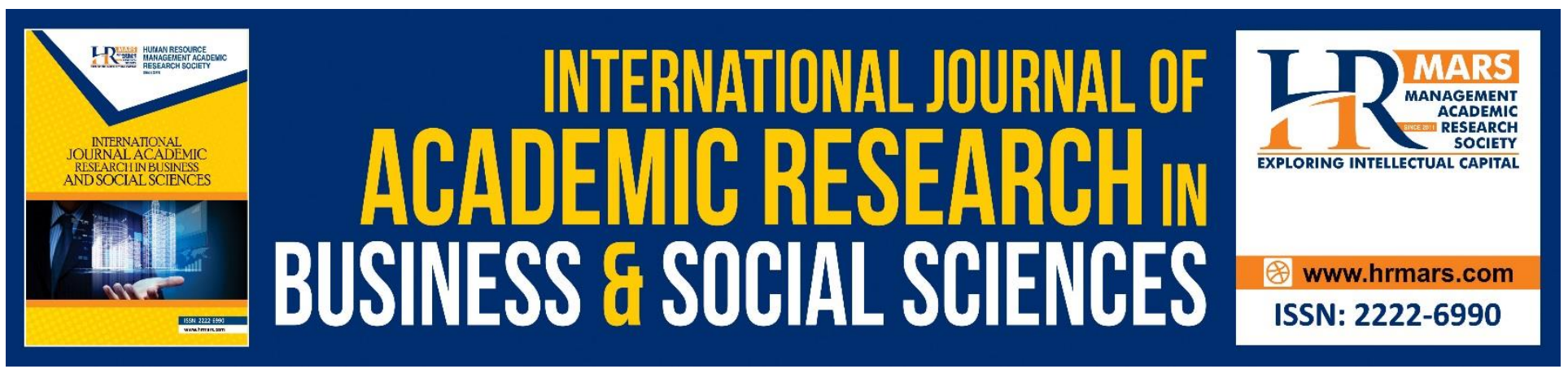

\title{
Protecting the Health of Children by Mandating Vaccination and Immunization: An Application of Usuli Principle of Istihsan
}

\author{
Nora Abdul Hak, Noraini Md Hashim \\ Department of Legal Practice, Ahmad Ibrahim Kulliyyah of Laws, International Islamic University \\ Malaysia, P.O. Box 10, 50728 Kuala Lumpur, Malaysia.
}

\section{Roslina Che Soh@Yusoff}

Department of Islamic Law, Ahmad Ibrahim Kulliyyah of Laws, International Islamic University Malaysia, P.O. Box 10, 50728 Kuala Lumpur, Malaysia.

\begin{abstract}
In 2016, the deaths of five children from diphtheria provoked an outcry among doctors and spurred calls for an edict by religious authorities to compel Muslim families to immunize their children. In relation to this issue, the Islamic Medical Association Malaysia (IMAM) has made a statement about a need to have the Malaysian children vaccinated as vaccination is proven to prevent infection. The association took a serious view of the recent cases of diphtheria, which had not appeared in Malaysia for a long time. What is more worrying is the fact that more children in Malaysia are falling victim to contagious diseases as parents reject immunization programs for fear the vaccines used infringe strict religious rules. In Islam, the stringent halal requirement can be waived if suitable vaccines are not available. By applying the principle of Islamic jurisprudence, although the vaccines contain a composition that is not permissible in Islam, for a reason of protection of health of children, it may be used for vaccination. There is an usuli principle of istihsan, which authorizes departure from an established ruling in favor of a different ruling as the latter is considered better on the basis of the Qur'an, Sunnah, Ijma', custom, necessity or maslahah. In this paper, Islamic legal research methodology is adopted. It involves a study of the relevant literature on the law (fiqh), the Qur'anic exegesis, the traditions of the Prophet Muhammad (hadith) and opinions of the four major schools of shariah relating to the principle of usul figh. The aim of this paper is to discuss the views of Muslim jurists on the application of istihsan as to whether or not vaccination and immunization should be made compulsory in order to protect the health of children in Malaysia.
\end{abstract}




\section{Introduction}

In Malaysia, the deaths of five children from diphtheria in 2016 provoked an outcry among doctors and spurred calls for an edict by religious authorities to compel Muslim families to immunize their children. Medical experts have blamed a growing anti-immunisation movement for the resurgence of diphtheria that had practically disappeared from the country (Malay mail Online, 2016, June 24). The NST reported Family Medicine Specialist Association of Malaysia president Dr Norsiah Ali as saying that the number of cases of preventable diseases have risen over recent years, such as measles from 235 cases in 2014 to 539 in 2016, pertussis from 497 cases in 2014 to 655 cases in 2016 and tetanus from 12 cases in 2014 to 22 in 2016 (Malay mail Online, 2016, June 24).

It was reported last year, i.e., 2016 that (according to official statistics) the number of parents refusing to immunize their children has tripled in the last three years from 470 to 1,282 (Pillay, 2016). The parents who refused to immunize their children have been largely influenced by anti-vaccination groups who blame vaccines for a range of health problems. It is important for us to know that many of the viruses and bacteria are still circulating in the country and that is why it is important that children receive the recommended immunizations on time (Pillay, 2016). Furthermore, nowadays Malaysians travel a lot, including to and from countries where many VPD (vaccine-preventable diseases) are common, thus it poses a very high risk to our children who are not immunized (Pillay, 2016).

In Islam, the stringent halal requirement can be waived if suitable vaccines are not available. By applying the principle of Islamic jurisprudence, although the vaccines contain a composition that is not permissible in Islam, for a reason of protection of health of children, it can be used for vaccination. Istihsan authorizes departure from an established ruling in favour of a different ruling as the latter is considered better on the basis of the Qur'an, Sunnah, Ijma', custom, necessity or maslahah. Thus, the main aim of this paper is to discuss the views of Muslim jurists on the application of istihsan as to whether or not vaccination and immunization should be made compulsory in order to protect the health of children in Malaysia.

\section{Methodology}

In this paper, Islamic legal research methodology is adopted (Zahraa, 1998). It involves a study of the relevant literature on the law (fiqh), the Qur'anic exegesis, the traditions of the Prophet Muhammad (hadith) and opinions of the four major schools of shariah relating to the principle of usul fiqh. The benefit of this methodology is that, through the study of the views of the Muslim jurists and the reasoning behind their legal rulings, the researchers will be able to understand the various schools of thought, to analyses them, to choose from among their interpretation and assign preference, and to adduce legal arguments on the basis of the principles formulated by these jurists (Al-Alwani, 1993). Therefore, it is believed that through this study a proper knowledge concerning the principle of istihsan and its application to the current problem will be acquired.

Islamic legal research methodology is based on the study of the sources of law as practiced by the Muslim jurists. The sources are categorized as primary i.e., the Qur'an and the Sunnah and, secondary sources such as ijma', qiyas, istihsan, sadd al-dhara'i and maslahah mursalah (Al-Alwani, 1993). The method of approach to legal issues of the four major thoughts in Islam are broadly similar with regard to the primary sources except for minor variation, where clear rulings are available in the primary 
INTERNATIONAL JOURNAL OF ACADEMIC RESEARCH IN BUSINESS AND SOCIAL SCIENCES Vol. 9, No. 5, May, 2019, E-ISSN: 2222-6990 @ 2019 HRMARS

sources (Al-Alwani, 1993). The opinions of the jurists however, vary on those legal rulings that are not expressly clear in the primary sources or those that are not available in the primary sources. If the text is not available in the primary sources, the jurists will use personal reasoning (ijtihad) to arrive at the solutions for prevailing the problem (al-Alwani, 1993).

\section{Results}

\section{Principles of Istihsan in Islam}

Istihsan literally means "to consider something good", "to approve", or "to deem something preferable". The root word of istihsan is 'hasuna' the meaning of which is 'being good' or 'beautiful' (Kamali, 2004). Abu al-Hasan al-Karkhi defines istihsan as a principle, which authorizes departure from an established precedent in favor of a different ruling for a reason stronger than the one, which is obtained in that precedent (Zahrah, 1958). On the definition of istihsan, al-Sarakhsi (1372 A.H.) commented, 'The precedent normally consists of an established analogy which may be abandoned in favor of a superior proof, that is the Qur'an, Sunnah, necessity (darurah), or a stronger qiyas.' Ibnu Taymiyyah (1965) defines istihsan as, "the abandonment of one legal norm (hukm) for another which is considered better on the basis of the Qur`an, Sunnah and ljma'." While, Ibn `Arabi (1330 A.H.) views that istihsan is 'to abandon exceptionally what is required by the law because applying the existing law would lead to a departure from some of its own objectives.'

From the definitions discussed above, it is observed that Maliki jurists emphasized on the principle of istislah, but in principle, they validated istihsan. Zaydan (1970) in his book states that "It is the departure from qiyas jalli to qiyas khafi or the making of an exception to a general rule of the existing law authorised by the dalil from Qur'an or Sunnah or ljma`or approved custom or daruriyyah or maslahah." According to Hassan (2005), Istihsan means to set aside the requirement of a proof as an exception, and to make concession in case of conflict of proofs. He further stated that the relevant proof is not set aside out of desire but because the proof which conflict it is stronger than it.

In relation to the definitions of istihsan, Kamali (2004) in his book states that the feature of istihsan, which is common to all the foregoing definitions, is the departure from an existing precedent on grounds of more compelling reasons. Zahrah (1958) viewed that al-Karkhi's definition embraces the essence of istihsan in all of its various forms. Zahrah (1958) further said the essence of istihsan is to formulate a decision which sets aside an established analogy for a reason that justifies such a departure and seeks to uphold a higher value of the Shariah.

Kamali has defined the term istihsan as follows; a method of exercising personal opinion in order to avoid rigidity and unfairness that might result from the literal enforcement of the existing law (Kamali, 2004). He then says istihsan is a juristic preference as it involves setting aside an established analogy in favour of an alternative ruling, which serves the ideals of justice and public interest in a better way (Kamali, 2004). He gives an example of Saidina Umar r.a whereby Saidina Umar did not impose hadd punishment during his time due to widespread famine. Saidina Umar set aside the established law in that case on grounds of public interest, equity and justice.

There are two types of Istihsan; firstly, is the departure from apparent analogy (qiyas jalli) to a hidden analogy (qiyas khafi), and secondly, is the departure from an existing ruling to a ruling which is given in the Qur'an, Sunnah, ljma', 'uruf or public interest. The departure is justified as enforcing the existing law may prove to be detrimental in certain situations and a departure from it may be the 
only way of attaining a fair solution to a particular problem. The Muslim jurist who resorts to istihsan may find the existing law to be either too general, or too specific and inflexible. Istihsan may offer a means of avoiding hardship and a solution, which is harmonious with the higher objectives of the Shariah (Kamali, 2004). Sarakhsi says istihsan is a method of seeking facility and ease in legal injunction. The departure in istihsan is to repel hardship and brings about ease to people (Kamali, 2004). Avoidance of hardship (raf' al-haraj) is a cardinal principle of religion as stated in the Qur'an (Al-Baqarah 2:185) and hadith "the best of your religion is, that which brings ease to the people" (Sarakhsi, 1324 A.H.). Kamali is of a view the rulings of the Companions were often based on the general spirit and purpose of the Shariah, and not necessarily on the narrow and literal meaning of its principles, and in this spirit istihsan was formulated (Kamali, 2004).

Istihsan is resorted to in the matter which the hukum is not clearly established by the Qur'an, Hadith or ljma`. Thus, it is not independent source of law (independent authority), and not superior to revelation. It offers solutions, which are based on principles upheld by Qur'an and Sunnah. Istihsan has played a significant role in the development of Islamic law as it bridged the gap between the law and social realities by enabling the jurists to pay individual attention to circumstances and peculiarities of a particular issue like this (vaccination and immunization). However, so far, it has not been utilized to the maximum of its potential.

\section{Some Facts about Vaccination and Immunization}

Immunization is the process whereby a person is made immune or resistant to an infectious disease, typically by the administration of a vaccine. Vaccines stimulate the body's own immune system to protect the person against subsequent infection or disease. Immunization is a proven tool for controlling and eliminating life-threatening infectious diseases (WHO, Immunization, http://www.who.int/topics/immunization/en/).

Each year, over 1.4 million children die from diseases that are preventable with readily available vaccines. These diseases include measles, meningitis caused by haemophilus influenza $B$, diphtheria, tetanus, yellow fever, polio and hepatitis B. Children who are immunized are protected from these dangerous diseases, which can often lead to disability or death (Facts for Life, at http://www.factsforlifeglobal.org/06/). All children have the right to this protection against diseases and early protection is critical. The immunizations in the child's first year and into the second year are especially important. Thus, parents need to know why immunization is important, and that it is actually safe to immunize their children.

Immunization prevents deaths every year in all age groups from many diseases such as diphtheria and measles. It is one of the most successful and cost-effective public health interventions. During 2016, an estimated 116.5 million children under the age of one year worldwide received three doses of diphtheria-tetanus-pertussis vaccine. These children are protected against infectious diseases that can cause serious illnesses (WHO, http://www.who.int/features/factfiles/immunization/en/).

Meningitis $A$ is an infection that can cause severe brain damage and is often deadly. Since the introduction of the meningitis A vaccine in Africa in December 2010, mass vaccination campaigns have led to the control and near elimination of the deadly meningitis A disease in 26 African "meningitis belt" countries. Measles is a highly contagious disease caused by a virus, which usually results in a high fever and rash, and can lead to blindness, or death. 
INTERNATIONAL JOURNAL OF ACADEMIC RESEARCH IN BUSINESS AND SOCIAL SCIENCES

Vol. 9, No. 5, May, 2019, E-ISSN: 2222-6990 @ 2019 HRMARS

Accelerated immunization activities have had a major impact on reducing measles deaths (WHO, http://www.who.int/features/factfiles/immunization/en/).

\section{Issues Arising from Vaccination}

It is claimed that vaccines contain chemically dangerous substances that may harm the body. This includes the claim that vaccines is linked to the development of autism in children and to be more specific autism is linked to the combined measles-mumps-rubella (MMR) vaccine (Saifuddeen, 2016). However, the studies conducted by the Centre for Disease Control (CDC) and Prevention, the American Academy of Pediatrics, Institute of Medicine of the US, National Academy of Sciences, UK National Health Service and the Cochrane Library found no evidence linking MMR vaccine to autism (Saifuddeen, 2016). It is reported that MMR is safe and effective in the prevention of diseases. Following the vaccine-autism controversy, vaccination compliance among community all over dropped. This has caused epidemic effects that are the increase of measles and mumps cases in the UK, disease outbreaks in Austria, Italy and Switzerland as reported by European Centre for Disease Prevention and Control (Saifuddeen, 2016).

The issue that arises in Malaysia is on the halal status of vaccine as it is clamed that vaccines that are produced contain haram substances. This has triggered reluctance among Muslim parents to vaccinate their children fearing that it is forbidden in Islam due to its contents (Saifuddeen, 2016). However, it is to be noted that in the event where there is no cure except the one that contains haram substance, Islam allows it on the basis of dharurat (Saifuddeen, 2016). There is an Islamic legal maxim, which says a dharurat situation permits that which is forbidden. There is already a list of fatwas from the National Fatwa Committee (NFC) regarding vaccination from 1998 to 2014. If there are no forbidden substances being used in the vaccines, such vaccines are permissible as the source is from cattle/bovine and not from swine/porcine.

In Malaysia, 80 per cent of the vaccines are halal. The NFC also views that even when there is a vaccine derived from non-halal sources, it is the collective responsibility of the Muslim ummah to create a demand for halal vaccines. Thus, pharmaceutical companies owned by Muslims or based in Muslim countries should take this as an obligation to develop halal vaccines. The ministry of Health Malaysia has given the assurance that there are no dangerous substances used in vaccines. Thimerosal, which is added as a preservative does not cause any toxic effect on the human body, as there is no evidence indicating such condition. Thus, it is safe to use it.

\section{Application of Istihsan to the Issue}

Istihsan plays an important role in Islamic law by developing Islamic legal reasoning through putting man's contribution into judgments based on principles of securing ease and avoiding hardship. Istihsan departs from a hukm that is backed by dalil and applies another hukm that is appropriate than the former based on dalil permitting such an action. Hanafis, Hanbalis and Malikis accepted istihsan as a proof of Shariah and their basis of accepting istihsan comes from verses 18 and 55 of surah al-Zumar. They also referred to a hadith of the Prophet Muhammad, which says, 'Harm is neither inflicted nor tolerated' and a statement of Ibn Mas'ud; "What the Muslims deem to be good is good in the sight of Allah SWT". Imam Shafi'e however, rejected istihsan as he considers this concept involves personal opinion, discretion and the inclination of the individual jurist, an exercise 
that is not in harmony with the Qur'an and Sunnah. He said adopting istihsan means following one's whim and amounts to unjustified legislation. It is said that Imam Shafie's objection of istihsan reflects the trend of ijtihad of his time. In the context of Islamic banking, istihsan has undoubtedly played a significant role in developing modern fiqh (Hasan, 2008).

In Islam, in order to cure the illness or diseases the use of medicine is encouraged and thus, it is not mandatory to resort to medication. However, those who opt to use medicinal means in order to prevent or combat disease, they should be respected and praised for their action. The ulama' is of the view that when a disease holds the potential of reaching pandemic proportions, the use of preventative medication becomes urgent as a social responsibility (VOCFM, 2017). Furthermore, the success of vaccination in curbing disease has been proven by medical studies. The Islamic Medical Association has emphasized the overall benefits of vaccinations in terms of the preservation/protection of the religion of Islam. Muslims who are vaccinated against vaccinepreventable diseases will be in a better position to uphold and practice all the obligations of Islam (VOCFM, 2017). The issue here is the use of non-halal substances in the vaccines by the Muslims.

With regard to this issue, the Muslim jurists have ruled that there are three conditions to be satisfied if the use of the impure substances as medicine is warranted. Firstly, lack of viable alternatives, secondly, the medicine is proven efficient and lastly, obliteration of the impure substance to the point where it cannot be traced (VOCFM, 2017 May 19). If we can afford to use pure alternatives we are very much encouraged to use them, however, in a situation we cannot find pure/halal alternatives, we are allowed to use the medication containing impure substances.

\section{Discussion}

Applying the principle of istihsan, it is permissible to use these vaccines containing haram substances if halal alternatives are not available or if it is too expensive. Muslims are duty bound to protect ourselves and communities from harm/darar and that vaccination is one of the methods of preventing the spread of diseases. Thus, it is submitted that in order to protect the life and health of the child; application of the principle of istihsan is justified by introducing a policy mandating vaccination and immunization on the children as an effort to prevent the spread of diseases. In Islam for example, strict rule requires that witnesses, in order to be admissible, must be 'adl. For judicial decisions must be founded on truth, and this is facilitated by the testimony of just witnesses. However if the court happens to be in a situation where 'adl witnesses cannot be found, then it is his duty, by virtue of istihsan, to admit witnesses who are not totally reliable so that the rights of the people may be preserved (Kamali, 2004, p. 257).

On the concept of dharurah, Jassas says dharurah means necessity, and he interprets its meaning in the verse 119 of surah al-An'am which says to the effect "He has explained in detail to you what He has forbidden you, excepting that to which you are compelled." The meaning of permissibility as mentioned in the verse may be referred to any kind of compulsion during danger (Kayadibi, 2010). It covers situations like when a person who is starving cannot find anything to eat except non-halal foods that are the only foods available at that time (Kayadibi, 2010). Hanafi scholars also consider the concept of ikrah as a necessity. For example, $A$ is threatened to be killed by $B$ if $A$ refuse to eat or drink something unlawful, then in that context, it becomes necessary for A to carry out B's command. If an act reaches the level of dharurat, it naturally becomes lawful (Kayadibi, 2010). There is a legal 
maxim, which says, "Necessity makes prohibited things permissible." According to Ali Haydar Afandi dharurat refers to a situation, which involves doing something by force or eating things that are forbidden by the religion (Kayadibi, 2010). Thus, dharurat is generally concerned with fear of destruction and threat to one of the five objectives of shariah, which must be protected from harm. In Perlis, the Fatwa Committee has decided that vaccination is the most effective method to prevent diseases and thus obligatory for Muslims to have them (Astro AWANI, 2016).

\section{Conclusion}

In Islam, the well-being of the Muslim ummah in terms of healthy body, mind and soul is very much emphasized, thus, vaccination, which is proven very effective in disease prevention is permissible based on the principle of istihsan (among others), where we may depart from the existing hukum in favour of alternative hukum on the basis of maslahah and necessity (dharurat). Although, the vaccine may contain substances considered haram, it is permissible for the Muslims to use if there are no other halal vaccines available. It was reported that recent outbreak of measles and rashes has increased following an anti-vaccine movement that rejected the vaccine injection for fear that it contains pig DNA. By applying the principle of istihsan, although the original hukum prohibits the usage of such vaccines, it becomes permissible as it offers protection of child's health, life and mind. Protection of life and health outweighs the obligation to abstain from utilizing vaccines/medicines considered haram for use. The advantages of immunization and vaccination take precedence over the alleged harms.

\section{Corresponding Author}

Nora Abdul Hak, Department of Legal Practice, Ahmad Ibrahim Kulliyyah of Laws, International Islamic University Malaysia, P.O. Box 10, 50728 Kuala Lumpur, Malaysia. Email: ahnora@iium.edu.my

\section{References}

1. Abu Zahrah, M. (1958). Usul al-Figh. Cairo: Dar al-Fikr al-Arabi.

2. Al-Alwani, T. J. (1993). Source Methodology in Islamic Jurisprudence. Virginia, USA: International Institute of Islamic Thought.

3. Al-Sarakhsi, S. M. (1372 A.H.) Usul al-Sarakhsi. Ed. Abu'I-Wafa al Afghani. Cairo: Matba'ah Dar al-Kitab al-Arabi.

4. Al-Sarakhsi, S. M. (1324 A.H.) al-Mabsut. Cairo: Matba'ah al-Sa'adah.

5. Bernama. (2016, November 11). Perlis Fatwa Committee makes it obligatory for Muslims to take vaccination. Astro AWANI, retrieved from http://english.astroawani.com/malaysianews/perlis-fatwa-committee-makes-it-obligatory-muslims-take-vaccination-122361

6. Hasan, A. (1970). The Early Development of Islamic Jurisprudence. Islamabad: Islamic Research Institute.

7. Hassan, H. H. (2005). An Introduction to the Study of Islamic Law. New Delhi: Adam Publishers and Distributors.

8. Ibn al-Arabi, A. A. (1330 A.H.) Ahkam al-Qur'an. Cairo: Matba'ah Dar al-Sa'adah. 
9. Ibn Taymiyyah, T. Mas'alah al-Istihsan. Trans. and ed. George Makdisi as Ibn Taymiyyah's Manuscript on Istihsan, in G. Makdisi, ed. (1965). Arabic and Islamic Studies in Honour of Hamilton A.R. Gibb. Leiden: E.J. Brill.

10. Kamali, M. H. (2004). Principles of Islamic Jurisprudence. Kuala Lumpur: Ilmiah Publishers. 4th print.

11. Malay mail Online. (2016, June 24). Anti-vaxxers to blame for diphtheria casualties, medical experts say. Retrieved from http://www.the malaymailonline.com/Malaysia/article/antivaxxers-to-blame-for-diphtheria-casuaties-mediacl-experts-say

12. New Straits Times. (2017, October 2). The Vaccination Dilemma by Suzanna Pillay. Retrieved from https://www.nst.com.my/news/2016/01/122580/vaccination-dilemma

13. Nyazee, I.A.K. (1993). Theories of Islamic law. Islamabad: Islamic Research Institute.

14. Saim, K. (2010). Istihsan: The Doctrine of Juristic Preference in Islamic Law. Petaling Jaya, Malaysia: Islamic Book Trust.

15. Saifuddeen, S. M., Shaikh M.S. (2016). Vaccination: Personal Choice vs. Public Interest.

16. VOCFM. (2017, May 19). Vaccination permissible, but 'with conditions': ulema. Retrieved from http://www.vocfm.co.za/vaccination-permissible-conditions-ulema/

17. World Health Organisation (WHO). (2017). 10 facts on Immunization. Retrieved from http://www.who.int/features/factfiles/immunization/en/

18. World Health Organization (WHO). (2017). Immunization. Retrieved from http://www.who.int/topics/immunization/en/

19. Zahraa, M. (1998). Research Methods for Law Postgraduate Overseas Student. Kuala Lumpur: Univision Press.

20. Zaydan, A. K. (1970). Al-Fard wa al-Dawlah fi al-Shariah al-Islamiyyah. Indiana: International Islamic Federation of Student Organization.

21. Zulkifli, H. (2008). Legal Thought of Mazhab al-Shafie in the Implementation of Islamic Banking in Malaysia. Retrieved from https//zulkiflihasan.files.wordpress.com/2008/05/jurnal-ikim20061.pdf.A 